\title{
DIAGNOSIS OF THE ENVIRONMENTAL CONDITIONS OF THE FUELS STATIONS IN GREATER BELEM
}

\author{
Paulo Sérgio do Livramento Magno \\ MBA em Perícia, Auditoria e Gestão Ambiental \\ Gustavo Aveiro Lins \\ CEDERJ/SEE-RJ/CEDAE \\ Josimar Ribeiro de Almeida \\ Escola Politécnica/UFRJ e Instituto de Química/UERJ \\ Roberto Ricardo Rachid Saab Barbosa Cunha \\ Observatório Urbano/UERJ/UN-Habitat \\ Manoel Gonçalves Rodrigues \\ Observatório Urbano/UERJ/UN-Habitat
}

\begin{abstract}
RESUMO
O combustível quando mal armazenado ou mal utilizado pode provocar graves riscos ambientais e físicos e como os postos de combustíveis apresentam características de empreendimentos potencialmente poluidores e geradores de acidentes ambientais, neste trabalho, está sendo apresentada uma diagnose da situação dos postos de combustíveis da cidade de Belém, Estado do Pará, por amostragem, com relação a sistema de instalação e armazenamento de derivados de petróleo e outros combustíveis, suas principais falhas causadoras de impactos causados ao meio ambiente por vazamentos, aos dispositivos de segurança, equipamentos necessários para se evitar elou conter os principais impactos como contaminação de águas superficiais e subterrâneas, contaminação do solo e outros riscos: incêndio ou explosão, previstos na legislação e normas específicas brasileiras. O objetivo é determinar as principais falhas no sistema de armazenamento nos postos de combustível e os principais impactos causados ao meio ambiente por vazamentos. $O$ trabalho foi desenvolvido pela coleta de dados e observação in loco de quinze postos de combustíveis na Região Metropolitana de Belém, escolhendo-se cinco postos para cada classe, de acordo com a Norma NBR 13786, excluindo-se a classe 0. Dentre os postos avaliados todos se encontram fora dos padrões, com exceção de um posto na classe III e outro na classe I. Constatou-se com o presente trabalho de campo que ainda alguns postos não estão atendendo a todas as normas em vigor, acredita-se que com o empenho dos proprietários e das companhias em proceder a uma modernização dos seus parques, bem como com uma fiscalização mais rigorosa dos órgãos competentes, este cenário modificar-se-á em pouco tempo.
\end{abstract}

Palavras-chave: Riscos ambientais. Armazenamento. Poluidores.

\begin{abstract}
Fuels, when improperly stored or misused, may cause grave environmental and physical risks and as the fuels stations present characteristics of potentially polluting enterprises and environmental accidents generators, this work presents a diagnosis of the situation of the fuels stations of Belém, Pará State, by sample, related to the system of installation and storage of petroleum derivatives and other fuels, their main failing which cause impacts over the environment due to leakage, safety devices, equipment that avoid and/or restrain the main impacts like superficial and subterranean waters contamination, soil contamination and other risks: fire or explosion in accordance with the legislation and Brazilian specific rules. The objective is to determine the main failures of the system of storage at fuels stations and the main impacts caused to environment due to leakage. The work was developed by using data collection and in loco observation of fifteen fuels stations in the
\end{abstract}


Metropolitan Region of Belém, by choosing five fuels stations from each class, according to the NBR 13786, excluding the class 0 . All the fuels stations which were observed were nonstandard, excepting one of the III class and other of the class 1 . The present field work found that there are some stations that still do not meet the current norms; it is believed that this scenery may be modified sooner due to owners' and companies efforts in conducting their parks modernization, as also as a more rigorous supervision by authorized bodies.

Keywords: Environmental Risks. Storage. Polluters

\section{INTRODUCTION}

Life in $20^{\text {th }}$ century has brought great changes for society, since the technological advance until great economic, social and environmental impacts, being presented whether in soil, water or atmosphere. These problems that disturb the great cities have generated enormous discussions and countless theses between all the sectors of the human knowledge (ALMEIDA, 2002). The propeller spring for this development has been the Petroleum that has provided to men great conquests, since mechanical basic machinery until spatial journeys, robots and etc. And when petroleum is the subject, the most daily used and the most important is the combustible supplied by the fuels stations for vehicles in cities: gas and diesel oil. The fuels stations present characteristics of potentially polluting enterprises and environmental accidents generators; in this work, a diagnosis of the environmental situation of the fuels stations in Belém city, Pará State, will be introduced, by sample, related to the system o installation and storage of petroleum derivatives and other fuels, their main failing reasons which cause impacts through leakage, the safety devices, required equipment to avoid and/or restrain the main impacts caused by superficial waters contamination (streams, rivers and beaches); subterranean waters contamination (underground water and aquifers); soil contamination and other risks: fire or explosion, met in legislation and specific Brazilian norms, CONAMA Resolution 273 of $29^{\text {th }}$ of November, 2000 and ABNT Norms NBR 13787 of March, 1997, ABNT NBR 14605 of October, 2000, ABNT NBR 13781 of June, 2001, ABNT NBR 14973 of $30^{\text {th }}$ of June, 2004, ABNT NBR 13783 of 29th of April, 2005, ABNT NBR 13786 of $31^{\text {st }}$ of May, 2005, ABNT NBR 15288 of $30^{\text {th }}$ of November, 2005; to prevent events occurrence and mitigate the harmful consequences to environment according to the classification of the fuels stations established by the legislation already specified.

The work was developed through a data collection and in loco observation of the environmental conditions related to equipment and systems of protection of environment of fifteen fuels stations of the Metropolitan Region of Belém, by 
choosing five stations of each class, according to the Norm ABNT NBR 13786, excluding the class 0 . It was opted to place letters instead of the Corporate Name in order to preserve the secrecy.

The services stations are classified in function of the analysis of the station surrounding, within a distance of $100 \mathrm{~m}$ from its perimeter. Identified the factor of aggravation of the surrounding ambience, the service station must be classified at the highest level, even there is only one factor of this class. This analysis allows the selection of equipment and systems to be applied for the "SASC". - ABNT NBR 13786/2005.

The Table 1 below shows the classification of each service station according to the surrounding ambience.

Table 1 - Classification of the services stations, according to the surrounding ambience.

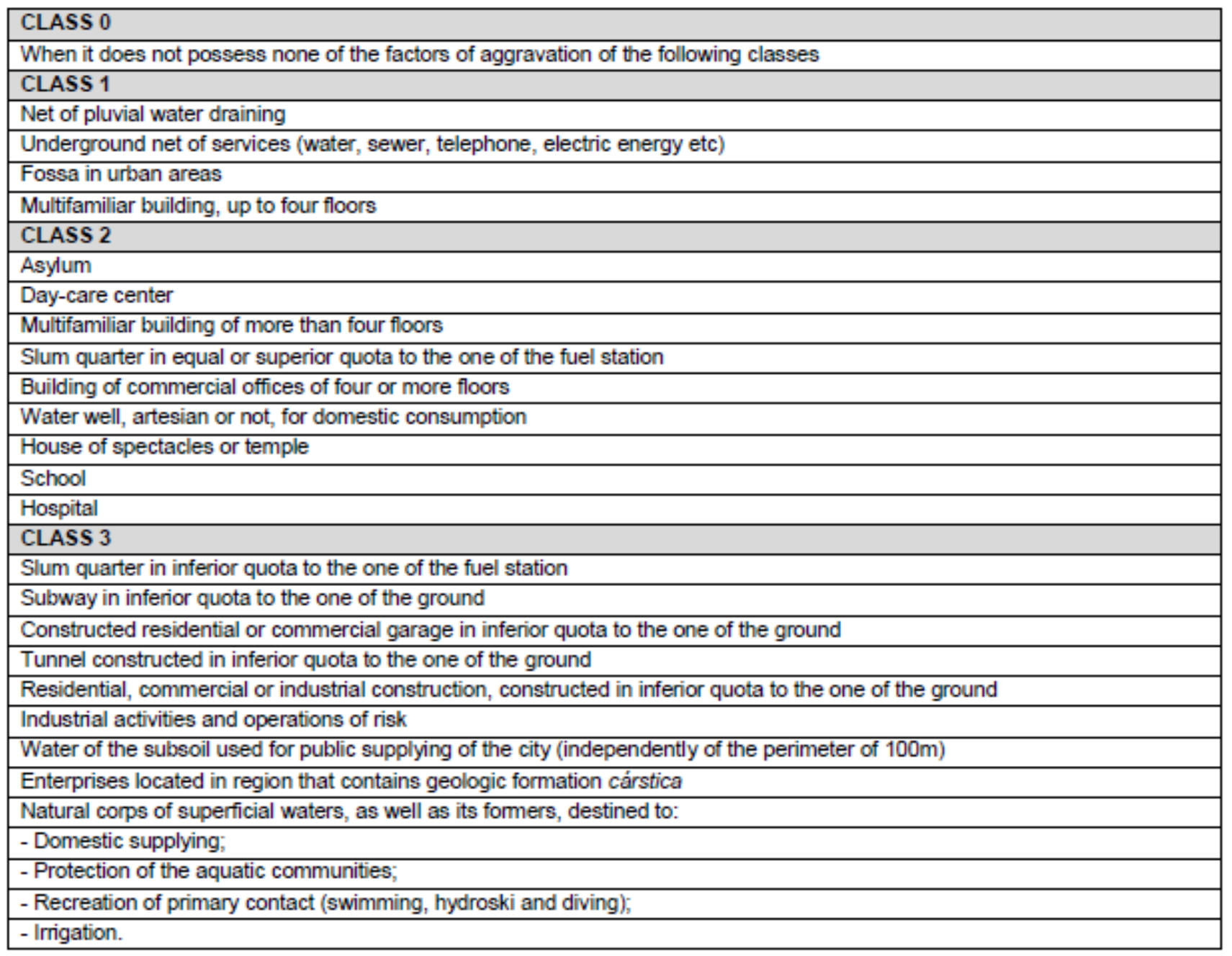




\section{BIBLIOGRAPHICAL REVIEW}

The Conselho Nacional do Meio Ambiente-CONAMA in the use of its competence and due to what is disposed in the Resolution CONAMA 237 of $19^{\text {th }}$ of December, 1997, created one new Resolution $n^{\circ} 237$ of $29^{\text {th }}$ of November, 2000, that regulates the construction, modification and expansion of enterprises which store and trade combustibles and obligates projects to be made according to technical norms launched by the Associação Brasileira de Normas Técnicas - ABNT and directives established by the authorized environmental body.

All installation and system of storage for petroleum derivatives and other fuels are configured as potentially polluting enterprises and environmental accidents generators.

All projects of construction, modification and expansion of enterprises must be obligatory conducted in accordance with the technical norms launched by the Associação Brasileira de Normas Técnicas - ABNT and directives established in the Resolutions CONAMA 273 or the authorized environmental body.

"In case of deactivation, the establishments must present a plan for activities closure to be approved by the authorized environmental body."

Any alteration in enterprises ownership or in their equipment and systems must be communicated to the authorized environmental body, aiming their update in the environmental permit." Resolution CONAMA 273 of $29^{\text {th }}$ of November, 2000.

Any occurrence of accidents or leakage must be communicated immediately to the authorized environmental body after singly or jointly confirmation and/or recognition, by the responsible ones for the business, equipment and systems.

Independent of the information about occurrence of accidents or leakage, the responsible ones for the establishment, equipment and systems will have to adopt the emergency actions required by the event, in the sense of minimize the risks and impacts over people and environment.

The proprietors of the establishments and the equipment and systems will have to promote the training, of its respective employees, aiming at to guide the actions of prevention of accidents and immediate suitable actions to control emergency situations. 
The subterranean tanks which present leakage will have to be removed after degassing and cleaning and be disposed according to the requirements of the authorized environmental body. Being proved that the removal technique is impossible, those will have to be degassed, cleaned, filled with inert material and sealed. - Resolution CONAMA 273 of $29^{\text {th }}$ of November, 2000.

The process of storage at fuels stations in Belém is of the type subterranean tanks, with sign for depressurization of the combustible inside them. Since the superior groundwater flows at high level, the tanks have to be "anchored" before being landed in and covered with the fuel station floor.

The Table 2 below shows the distribution of the safety equipment agreeing with the standard established by the current legislation according to the respective classes.

Table 2 - Distribution of equipment in accordance with the legislation.

\begin{tabular}{|c|c|c|c|}
\hline Accident & Class 1 & Class 2 & Class 3 \\
\hline \multirow{5}{*}{ Leakage } & An only valve of retention next to the suction of the bomb. & \multirow{2}{*}{ Options of the class 1} & \multirow{2}{*}{$\begin{array}{l}\text { Options of the class } 2 \\
\text { Interstitial monitoring. }\end{array}$} \\
\hline & Well of monitoring of underground water or vapors or test of leakage. & & \\
\hline & $\begin{array}{l}\text { Control of monthly supply by the LMC or control of automatic supply (that detects loss of } 1 \mathrm{~L} / \mathrm{h} \text {. } \\
\text { with } 95 \% \text { of possibility of rightness and } 5 \% \text { of false alarm). } \\
\text { Splitting box of water and oil }\end{array}$ & \multirow[t]{3}{*}{ Options of the class 1} & \multirow{3}{*}{$\begin{array}{l}\text { Options o1f the class } 2 \\
\text { and chamber1 of } \\
\text { Spilling }\end{array}$} \\
\hline & Chamber of access to the visit mouth & & \\
\hline & supplier unit projection of the covering of the bombs. & & \\
\hline Overflow & $\begin{array}{l}\text { Sealed discharge } \\
\text { Chamber of containment of sealed. }\end{array}$ & $\begin{array}{l}\text { Options of the class } 1 \\
\text { discharges Valve of } \\
\text { protection against } \\
\text { overflow Alarm for } \\
\text { overflow } \\
\text { Valve of retention of } \\
\text { floating sphere. }\end{array}$ & Options of the class 2 . \\
\hline \multirow{4}{*}{$\begin{array}{l}\text { Corrosion in } \\
\text { underground } \\
\text { tanks }\end{array}$} & \multirow{4}{*}{ Any options of the class 2} & $\begin{array}{l}\text { Tank manufactured in } \\
\text { nonmetallic material } \\
\text { according to the NBR } \\
13212 \text {. }\end{array}$ & $\begin{array}{l}\text { Tank of double wall } \\
\text { factured in steel } \\
\text { carbon, according } \\
\text { tothe NBR } 13785 \text {, with } \\
\text { resistant external } \\
\text { corrosion and cathodic. }\end{array}$ \\
\hline & & $\begin{array}{l}\text { Tank manufactured in } \\
\text { steel covering against } \\
\text { carbon, according to } \\
\text { the NBR } 13312 \text {, with } \\
\text { resistant external } \\
\text { corrosion and cathodic. }\end{array}$ & $\begin{array}{l}\text { Tank of double wall } \\
\text { manufactured in steel } \\
\text { carbon, according to } \\
\text { the NBR } 13785 \text {, with } \\
\text { with extemal covering } \\
\text { against corrosion and } \\
\text { that excuses the } \\
\text { cathodic protection. }\end{array}$ \\
\hline & & \multirow[t]{2}{*}{$\begin{array}{l}\text { Any options of the } \\
\text { class } 3\end{array}$} & $\begin{array}{l}\text { Tank of double wall } \\
\text { manufactured in steel } \\
\text { carbon, being the last } \\
\text { one of nonmetallic } \\
\text { material, according to } \\
\text { the NBR } 13785\end{array}$ \\
\hline & & & $\begin{array}{l}\text { Tank of double wall } \\
\text { manufactured in } \\
\text { nometallic material }\end{array}$ \\
\hline
\end{tabular}

\section{METHODOLOGY}

The work was conducted through data collection through field research. It was observed if the fifteen fuels stations which were verified had all the safety equipment 
for environment, in the Metropolitan Region of Belém, by choosing fives stations from each class, according to the Norm ABNT NBR 13786, excluding the class 0 . It was opted to place letters instead of the Corporate Name in order to preserve the secrecy.

\section{RESULTS AND DISCUSSIONS}

The Table 3 shows the results from the field research conducted at the fifteen fuels stations of Greater Belém, represented by the letters $A$ to $O$, with their respective classes and installed equipment.

Table 3 - Results from the field research taken at fifteen fuels stations in Greater Belém.

\begin{tabular}{|c|c|c|c|c|c|c|c|c|c|c|c|c|c|c|c|c|}
\hline \multirow{3}{*}{ Accident } & \multirow{3}{*}{ Equipment } & \multicolumn{15}{|c|}{ Fuel Stations } \\
\hline & & \multicolumn{6}{|c|}{ Class 3} & \multicolumn{5}{|c|}{ Class 2} & \multicolumn{4}{|c|}{ Class 1} \\
\hline & & $\mathrm{A}$ & $\mathrm{B}$ & $\mathrm{C}$ & $\mathrm{D}$ & $\mathrm{E}$ & $F$ & $G$ & $\mathrm{H}$ & I & $\mathrm{J}$ & $\mathrm{K}$ & $\mathrm{L}$ & $\mathrm{M}$ & $\mathrm{N}$ & 0 \\
\hline \multirow{6}{*}{ Leakage } & Valved of retention next to the suction of the bomb & $\mathrm{X}$ & $\mathrm{X}$ & $\mathrm{X}$ & $\mathrm{X}$ & $\bar{X}$ & $\mathrm{X}$ & $\mathrm{X}$ & $\mathrm{X}$ & $\mathrm{X}$ & $\mathrm{X}$ & $\mathrm{X}$ & $\mathrm{X}$ & $\mathrm{X}$ & $\mathrm{X}$ & $\mathrm{X}$ \\
\hline & Well of monitoring of underground water or vapors & & $\mathrm{X}$ & & & $\mathrm{X}$ & & & & & & & & & & $\mathrm{X}$ \\
\hline & Leakage test & & $\mathrm{X}$ & & & $\mathrm{X}$ & $\mathrm{X}$ & & & & & $X$ & $X$ & & & $\mathrm{X}$ \\
\hline & Control of monthly supply by the LMC & $\mathrm{X}$ & $\mathrm{X}$ & $\mathrm{X}$ & $\mathrm{X}$ & $\mathrm{X}$ & $\mathrm{X}$ & $\mathrm{X}$ & $\mathrm{X}$ & $\mathrm{X}$ & $\mathrm{X}$ & $\mathrm{X}$ & $\mathrm{X}$ & $\mathrm{X}$ & $\mathrm{X}$ & $\mathrm{X}$ \\
\hline & $\begin{array}{l}\text { Control of automatic supply (that detects loss of } 1 \mathrm{~L} / \mathrm{h} \text {. with } 95 \% \text { of } \\
\text { possibility of rightness and } 5 \% \text { of false alarm) }\end{array}$ & & $\mathrm{X}$ & & & & & & & & & & & & & \\
\hline & Interstitial monitoring & & $\mathrm{X}$ & & & & & & & & & & & & & \\
\hline \multirow{4}{*}{ Spilling } & Splitting box for water and oil & & $\mathrm{X}$ & & & & $\mathrm{X}$ & $\mathrm{X}$ & $\mathrm{X}$ & $\mathrm{X}$ & $\mathrm{X}$ & & & & & $\mathrm{X}$ \\
\hline & Chamber of access to the visit mouth & & $\mathrm{X}$ & & & & & $\mathrm{X}$ & $\mathrm{X}$ & $\mathrm{X}$ & $\mathrm{X}$ & $\mathrm{X}$ & $\mathrm{X}$ & & & $\mathrm{X}$ \\
\hline & $\begin{array}{l}\text { Narrow channels of containment in the projection of the of the covering of } \\
\text { the bombs }\end{array}$ & & $\mathrm{X}$ & & & & $\mathrm{X}$ & $\mathrm{X}$ & $\mathrm{X}$ & $\mathrm{X}$ & $\mathrm{X}$ & $\mathrm{X}$ & $\mathrm{X}$ & & & $\mathrm{X}$ \\
\hline & Chamber of containment under the supplier unit. & & $\mathrm{X}$ & & & & & & & & & & & & & $\mathrm{X}$ \\
\hline \multirow{5}{*}{ Overflow } & Sealed discharge & & $\mathrm{X}$ & $\mathrm{X}$ & & & $\mathrm{X}$ & $\mathrm{X}$ & $\mathrm{X}$ & $\mathrm{X}$ & $\mathrm{X}$ & $\mathrm{X}$ & $\mathrm{X}$ & $\mathrm{X}$ & & $\mathrm{X}$ \\
\hline & Chamber of containment of sealed discharges & & $\mathrm{X}$ & & & & & & & & & & & & & $\mathrm{X}$ \\
\hline & Valve of protection against overflow & & $\mathrm{X}$ & & & & & & & & $\mathrm{X}$ & $\mathrm{X}$ & $\mathrm{X}$ & $\mathrm{X}$ & & $\mathrm{x}$ \\
\hline & Alarm for overflow & & $\mathrm{X}$ & & & & & & & & & & & & & \\
\hline & Valve of retention of floating sphere & & $\mathrm{X}$ & & & & & & & & & & & & & \\
\hline \multirow{3}{*}{$\begin{array}{c}\text { Corrosion in } \\
\text { underground } \\
\text { tanks }\end{array}$} & Tank manufactured in nonmetallic material according to the NBR 13212 & & & $\mathrm{X}$ & $\mathrm{X}$ & $\mathrm{X}$ & $\mathrm{X}$ & & & & & & & $\mathrm{X}$ & $\mathrm{X}$ & \\
\hline & $\begin{array}{l}\text { Tank manufactured in steel carbon, according to the NBR 13312, with } \\
\text { resistant extermal against corrosion and cathodic protection. }\end{array}$ & & & & & & & & & & & & & & & \\
\hline & $\begin{array}{l}\text { Tank of double wall manufactured in steel carbon, according to the NBR } \\
13785 \text {, with external covering against corrosion and cathodic protection. }\end{array}$ & & & & & & & & & & & & & & & \\
\hline
\end{tabular}

\section{FINAL CONSIDERATIONS}

Amongst the fuels stations which were evaluated, all of them considered nonstandard, excepting one of the class 3 and another of the class 1 . These are the highlighted reasons:

Environment matters are recent. Laws and NBR have been gradually issued. The environmental bodies started to prepare their staffs for supervising and licensing 
aiming to fulfill the current legislation. The established fuels stations were given a period to be adapted to the new requirements.

There was a resistance of entrepreneurs, even with the trade union movement and actions in court to avoid compliance with the legislation, because there were high costs involved with the replacement of tanks, which required excavation and preparation of installations for the purpose of receiving new tanks and accessories as well as the legalization of the fuels stations.

The flags sought to gain time in the presentation of the old tanks replacement schedule and distribution lines (pipes) for environmental bodies, scheduling changes to dates far ahead and making a few substitutions per year. But in the last twelve months it is observed that this procedure has changed a great deal. Not only the posts has sought to comply with current legislation as the flags has sought to equip their outposts with modern tanks and equipment, even deploying programs of monitoring the quality of fuel sold.

For this reason, it was confirmed with this field work that even some fuels stations are not meeting all current standards. But it is believed that with the commitment of the owners and of the flags to undertake a modernization of its parks, as well as stricter supervision of competent bodies, this scenario will change soon.

\section{REFERENCES}

ABNT NBR 13787 de março de 1997.

ABNT NBR 14605 de outubro de 2000.

ABNT NBR 13781 de junho de 2001.

ABNT NBR 14973 de 30 de junho de 2004.

ABNT NBR 13783 de 29 de abril de 2005.

ABNT NBR 13786 de 31 de maio de 2005.

ABNT NBR 15288 de 30 de novembro de 2005.

ALMEIDA, J.R. (ORG.). Ciências Ambientais. Ed. Thex. Rio de Janeiro. 482p. 2002 
AZEVEDO NETTO, J.M. Tratamento de água. Ed. Edgard Blucher Ltda. Water Research, vol. 25 no 8, pg. 985-993. 1995.

BRAGA BENEDITO at all. Introdução a Engenharia Ambiental. Escola Politécnica da USP, 2002.

Lei Ambiental do Estado do Pará, Lei o 5.887 de 09 de maio de 1995. Dispõe sobre a Política Estadual do Meio Ambiente e dá outras providências.

RESOLUÇÃO CONAMA 273 de 29 de novembro de 2005

Richter, C.A. Tratamento de Água - Tecnologia Atualizada. Editora Edgar Blücher Ltda. 2000. 